\title{
Chromosomal Abnormality, Megaloblastosis, and Arrested DNA Synthesis in Erythroleukaemia
}

\author{
P. E. CROSSEN, P. H. FITZGERALD, R. C. MENZIES, and L. A. BREHAUT \\ From Cytogenetics Unit, ${ }^{\star}$ Christchurch Hospital, Christchurch, New Zealand
}

Chromosomal studies of bone-marrow cells have been reported on 30 patients with erythroleukaemia (Table I). Some of these reports give only meagre cytogenetic details, but there was an increased degree of polyploidy in at least 9 of the patients, significant aneuploidy in 12 , and structural abnormalities in 11. Some patients showed more than one of these features, and only 8 patients had normal chromosomes. For several reasons these reports probably do not give a reliable estimate of the incidence of cytogenetic abnormality in erythroleukaemia, but they do indicate that structural changes, which are often associated with hypodiploid numbers, and polyploidy are prominent features of this leukaemia. The structural abnormalities included separate instances of chromosome breakage in different cells of untreated patients (Heath and Moloney, 1965; Weatherall and Walker, 1965; Jensen, 1966), and also the presence of cytogenetically abnormal cell lines, the most notable being the ring chromosomes described in two patients (Di Grado, Mendes, and Schroeder, 1964; Jensen, 1966).

We report a further patient with erythroleukaemia whose bone-marrow showed megaloblastoid features, chromosome structural aberrations, including a cell line with a ring chromosome, polyploidy, and an associated abnormality of DNA synthesis.

\section{Case History}

A 72-year-old woman presented with severe anaemia on July 26, 1967. Haematological details were as follows.

Blood: haemoglobin, 7.5 g. $/ 100 \mathrm{ml}$; PCV, $22 \%$; ESR, $74 \mathrm{~mm}$./hr.; platelets, 80,000/cu. mm.; reticulocytes, $1.3 \%$; WBC, $4000 /$ cu. $\mathrm{mm}$.

The white cells had a normal distribution, though $4_{\%}^{\circ} \%$ myelocytes were present. The blood contained $2 \%$

\footnotetext{
Received June 11, 1968.

* Supported by the Canterbury and Westland Division of the Cancer Society of New Zealand.
}

nucleated red cells and the mature red cells showed anisocytosis and poikilocytosis.

Marrow: blasts, $0.8 \%$; myelocytes, $11.6 \%$; polymorphonuclears, $27.6 \%$; lymphocytes, $4.8 \%$; megakaryocytes, $0.4 \%$; plasma cells, $1.6 \%$; pro-erythroblasts, $12.0 \%$; early erythroblasts, $4.4 \%$; late erythroblasts, $36.8 \%$; $M:$ E ratio, $1: 1 \cdot 3$.

Erythropoiesis was clearly hyperplastic. Most of the erythroblasts were atypical with fine reticular nuclei, distinct nucleoli, and vacuoles in the cytoplasm. Megaloblastoid changes were present. Some erythroblasts contained coarse PAS positive granules and others were multinucleate with $2,3,4$, or more nuclei. Myeloid maturation was normal. Free iron was demonstrated in the marrow. Serum B12 and folate were within the normal range. The diagnosis was acute leukaemia of the Di Guglielmo type.

The patient enjoyed a short remission after transfusions of packed cells and whole blood. However by

TABLE I

CHROMOSOME FINDINGS IN 30 PUBLISHED CASES OF ERYTHROLEUKAEMIA

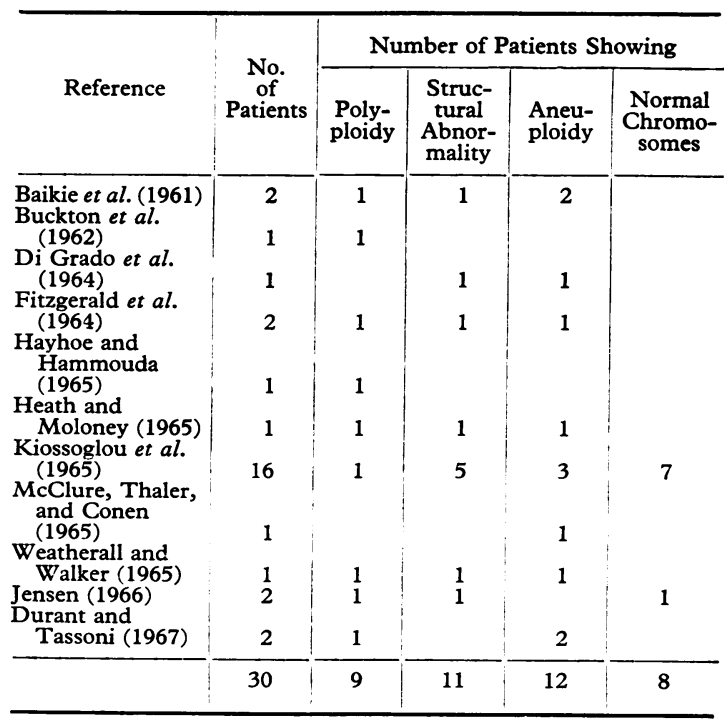


September 5, the haemoglobin was 6 g., and PCV 19\%, and there were $4 \%$ nucleated red cells in the blood. In spite of further transfusions, her condition deteriorated and she died on October 19, 1967. Necropsy revealed a cerebral infarct and acute erythroblastic leukaemia. The bone-marrow was very hypercellular, with large masses of primitive cells and many megakaryocytes.

The patient's family showed an unusually high incidence of cancer. Her father had carcinoma of the throat, her mother and sister carcinoma of the bowel, and another sister died of leukaemia.

\section{Methods}

For chromosome examination, bone-marrow cells were prepared according to the direct method of Tjio and Whang (1962), blood leucocytes were cultured with phytohaemagglutinin and prepared according to the method of Moorhead et al. (1960), and skin cells were cultured as described by Harnden and Brunton (1965).

For autoradiographic and microdensitometric studies, newly aspirated bone-marrow cells were suspended in Hanks solution containing tritiated thymidine at a con- centration of $2 \mu \mathrm{Ci} / \mathrm{ml}$. Following hypotonic treatment and fixation in acetic-methanol, as described previously (Menzies et al., 1966), the cells were spread by airdrying and stained by the Feulgen technique. The slides were then covered with Kodak AR 10 stripping film, exposed for 3 days, and developed in Kodak D19b developer. The number of tritium-labelled cells was determined in a count of 500 mononuclear non-segmented cells. Labelled and unlabelled Feulgen-stained cells were identified and marked separately on photographic maps of the slides, and the silver grains were removed from the film by a $10 \%$ solution of potassium ferricyanide as described by Balfour, Cooper, and Meek (1965). The light absorption of Feulgen-stained nuclei was then measured in 100 marked labelled cells and in 100 marked unlabelled cells by a Barr and Stroud GN2 integrating microdensitometer. The density of Feulgen staining was taken to be a measure of cell DNA content.

\section{Results}

Chromosome Studies. Cells from the bonemarrow had abnormal modal counts of 44 and 45

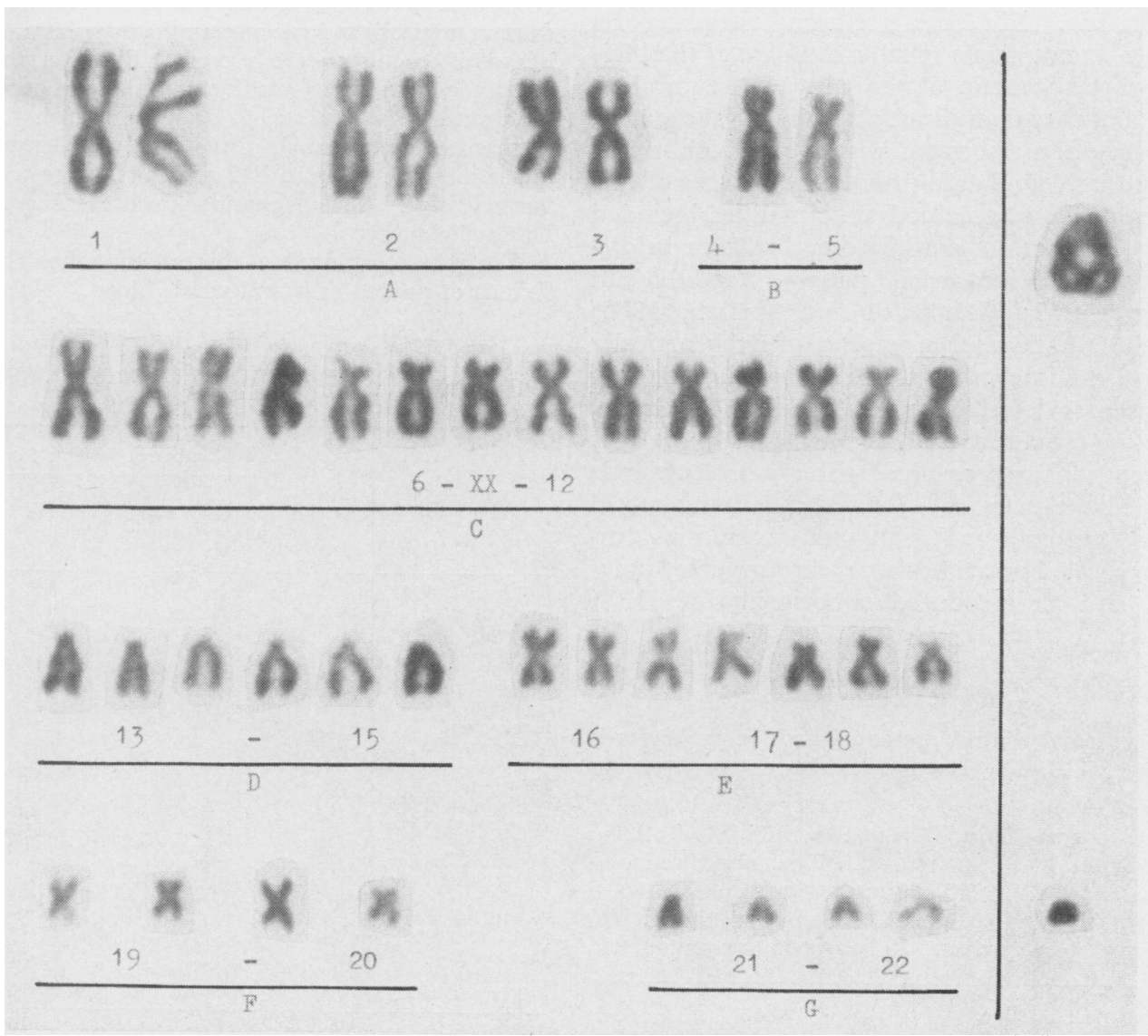
Fig. 1. Bone-marrow cell type 1 . Two $\mathrm{B}$ and two $\mathrm{C}$ chromosomes are missing. There is an additional $\mathrm{E}$ chromosome, a large ring
chromosome, and a minute element. Total 45 chromosomes. 
chromosomes (Table II). A ring chromosome was prominent in $86 \%$ of these cells. The ring varied in size between cells but two forms predominated, one being about twice the size of the other (Fig. 1-6). A few cells contained 2 and 3 ring chromosomes of similar size, which probably had accumulated as a result of nondisjunction of an original ring chromosome. Karyotype analyses of 18 marrow cells showed several related sublines with common chromosomal abnormalities (Table III). All cells analysed lacked 2 chromosomes of the B group and usually 1 or more members of the $C$ group. The four most common cell types showed the ring chromosome, but differed from each other in the number of $\mathrm{C}$ group chromosomes and in the presence of two additional elements: a chromosome
TABLE II

CHROMOSOME COUNTS IN MARROW CELLS, PHA-CULTURED LEUCOCYTES, AND CULTURED SKIN CELLS

\begin{tabular}{lrr|r|r|r|r|r|r}
\hline & \multicolumn{3}{c}{ No. of Chromosomes } & Total \\
\cline { 2 - 5 } & 42 & 43 & 44 & 45 & 46 & 47 & Cells \\
\hline $\begin{array}{l}\text { Bone-marrow (direct) } \\
\begin{array}{l}\text { Leucocyte culture } \\
\text { Skin culture }\end{array}\end{array}$ & 3 & 4 & 13 & 24 & 3 & 2 & 49 \\
\hline
\end{tabular}

similar to members of the $\mathrm{E}$ group, and a minute element, possibly also a ring, about the size of a $\mathrm{G}$ group chromosome (Fig. 1-4). Other karyotypes represented cells with multiple rings (Fig. 5), a ring and a dicentric chromosome (Fig. 6), and a cell without the ring chromosome.

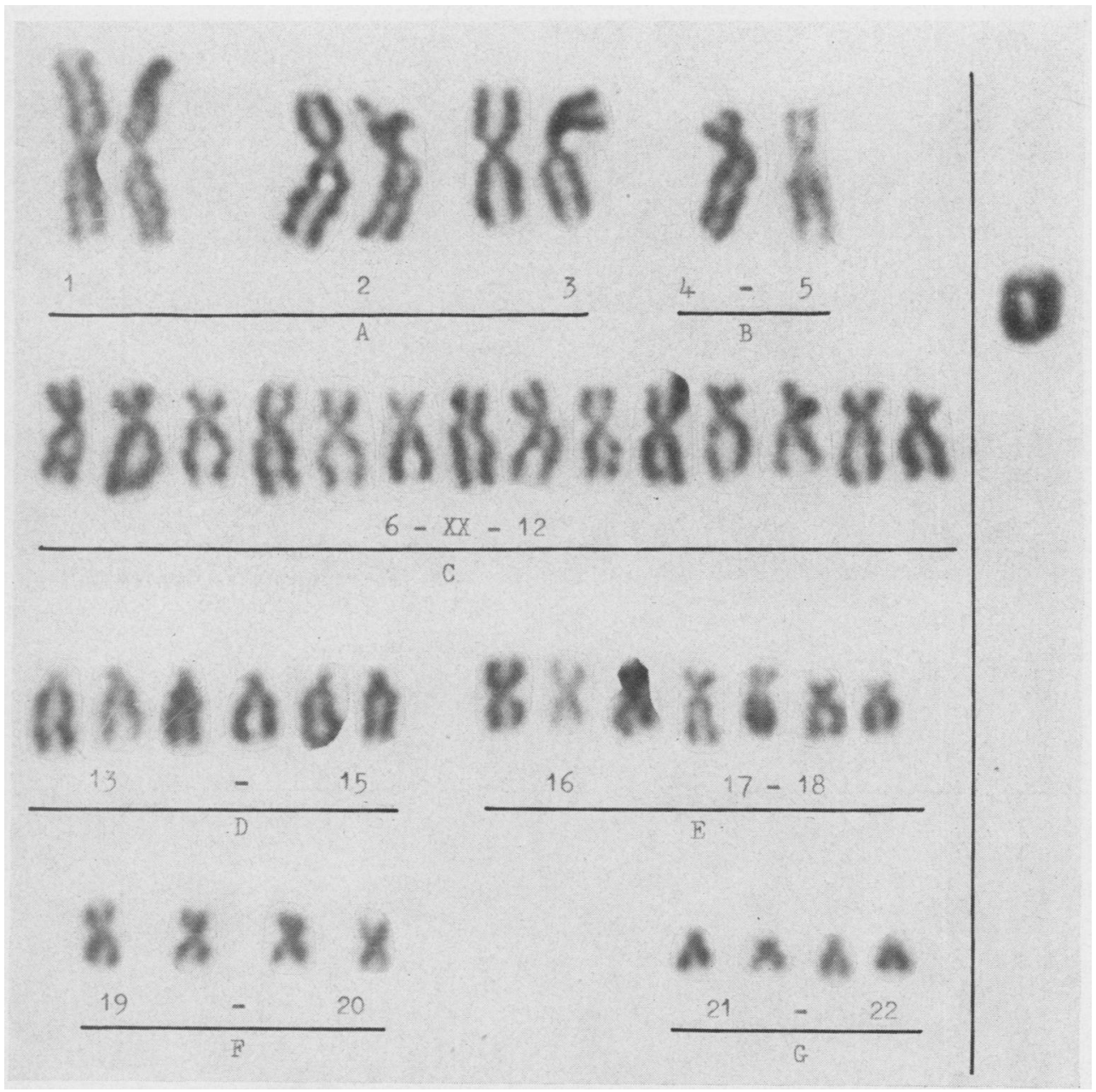

Fig. 2. Bone-marrow cell type 2. Two $\mathrm{B}$ and two $\mathrm{C}$ chromosomes are missing. There is an additional $\mathrm{E}$ chromosome and a large ring chromosome. Total 44 chromosomes. 
TABLE III

KARYOTYPE ANALYSES OF 18 BONE-MARROW CELLS

\begin{tabular}{|c|c|c|c|c|c|c|c|c|c|c|c|}
\hline $\begin{array}{l}\text { Cell } \\
\text { Type }\end{array}$ & $A(6)$ & $\underset{B(4)}{\text { Num }}$ & $\begin{array}{c}\text { Deviatio } \\
\text { ber in } C \\
\text { C(16) }\end{array}$ & $\begin{array}{c}\text { On from } \\
\text { Chromo } \\
D(6)\end{array}$ & $\begin{array}{l}\text { Normal } \\
\text { some Groups } \\
E(6) \quad F(4)\end{array}$ & $G(4)$ & $\begin{array}{r}\text { Ad } \\
\text { Ab } \\
\text { Chro }\end{array}$ & $\begin{array}{l}\text { Iditional } \\
\text { onormal } \\
\text { mosomes }\end{array}$ & $\begin{array}{c}\text { No. of } \\
\text { Chromosomes }\end{array}$ & $\begin{array}{l}\text { No. of } \\
\text { Cells }\end{array}$ & $\begin{array}{l}\text { Fig. } \\
\text { No. }\end{array}$ \\
\hline $\begin{array}{l}1 \\
2 \\
3 \\
4\end{array}$ & & $\begin{array}{l}-2 \\
-2 \\
-2 \\
-2\end{array}$ & $\begin{array}{l}-2 \\
-2 \\
-1 \\
-1\end{array}$ & & $\begin{array}{l}+1 \\
+1 \\
+1\end{array}$ & & $\begin{array}{l}\mathbf{r} \\
\mathbf{r} \\
\mathbf{r} \\
\mathbf{r}\end{array}$ & $\begin{array}{l}\mathbf{m} \\
\mathbf{m}\end{array}$ & $\begin{array}{l}45 \\
44 \\
45 \\
45\end{array}$ & $\begin{array}{l}5 t \\
2 \\
4 \ddagger \\
3\end{array}$ & $\begin{array}{l}1 \\
2 \\
3 \\
4\end{array}$ \\
\hline $\begin{array}{l}5 \\
6 \\
7 \\
8\end{array}$ & $\begin{array}{l}+1 \\
+1\end{array}$ & $\begin{array}{l}-2 \\
-2 \\
-2 \\
-2\end{array}$ & $\begin{array}{l}-3 \\
-2 \\
-3\end{array}$ & -1 & $\begin{array}{l}+1 \\
+1\end{array}$ & & $\begin{array}{l}2 \mathbf{r} \\
3 \mathbf{r} \\
\mathbf{r}\end{array}$ & $\underset{\mathbf{m}}{\mathbf{m}}$ dic & $\begin{array}{l}45 \\
46 \\
44 \\
45\end{array}$ & $\begin{array}{l}1 \\
1 \\
1 \\
1\end{array}$ & $\begin{array}{l}5 \\
6\end{array}$ \\
\hline
\end{tabular}

* Abnormal chromosomes: $r$, ring; $m$, minute; dic, dicentric.

+1 cell of this type also lacked a $G$ chromosome, total 44 chromosomes.

$¥ 1$ cell of this type also lacked an $\mathrm{F}$ chromosome, total 44 chromosomes.

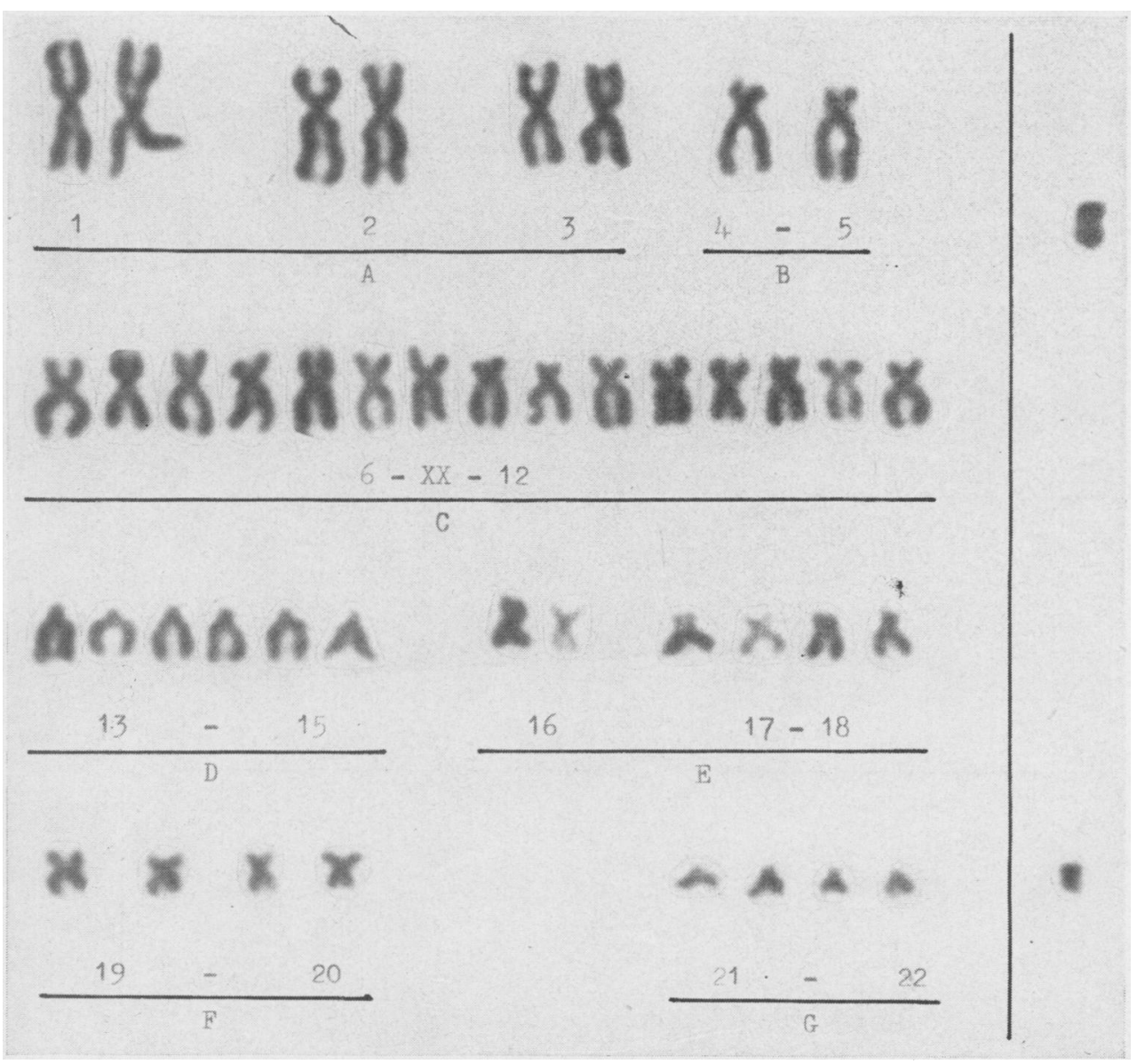

Fig. 3. Bone-marrow cell type 3. Two $B$ and one $C$ chromosomes are missing. A small ring chromosome and a minute element are $O$ present. Total 45 chromosomes. 
Approximately $14 \%$ of the marrow cells showed other evidence of chromosome breakage, mostly breaks and gaps. This contrasts with an average $1.5 \%$ incidence of breaks and gaps in bone-marrow cells from 15 other patients with untreated leukaemia. $7 \%$ of the marrow cells were polyploid, most commonly tetraploid but also octoploid. The polyploid cells contained ring chromosomes and other structural abnormalities (Fig. 7).

There was no evidence of the ring chromosome or of abnormal chromosome numbers in leucocytes cultured with phytohaemagglutinin and in cultured skin cells (Table II), but 2 of the 16 leucocytes and 2 of the 25 skin cells showed chromosome breaks. It is difficult to attach any significance to these low counts, though breaks are rarely found in cells from normal persons after culture in this laboratory.

DNA Studies. $14 \%$ of the mononuclear, nonsegmented marrow cells were labelled with ${ }^{3} \mathrm{H}$-thymidine, compared with our observed mean values of $11 \% \pm 4 \%$ for normal marrows and $20 \% \pm 10 \%$ for megaloblastic marrows.

The DNA contents of non-segmented mononuclear marrow cells were determined by the microdensitometer, the labelled and unlabelled cells being measured separately. The distribution of DNA content in unlabelled cells of a normal marrow characteristically shows well-defined modes at $2 \mathrm{n}$ and at $4 n$, representing cells which have not started DNA synthesis and cells which have completed

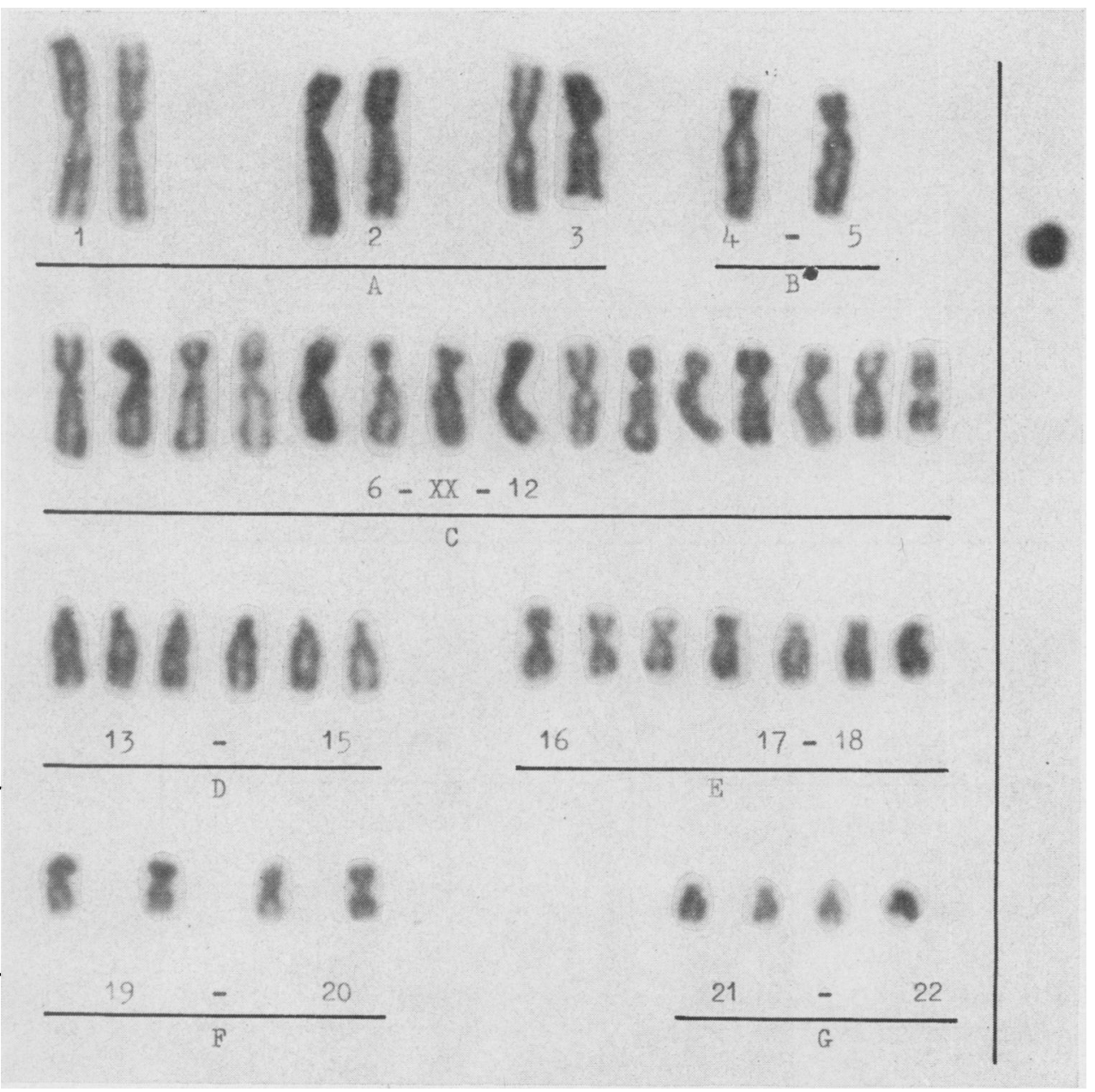

Fig. 4. Bone-marrow cell type 4. Two $B$ and one $C$ chromosomes are missing. There is an additional $E$ chromosome and a small ring chromosome. Total 45 chromosomes. 
DNA synthesis respectively (Fig. 8). DNA measurements of unlabelled marrow cells from the patient with erythroleukaemia differed from the normal distribution in two respects. First, the $2 \mathrm{n}$ and 4n modes had increased spreads, and secondly, about $10 \%$ of the unlabelled cells had amounts of DNA between the $2 n$ and $4 n$ modes (Fig. 9). The DNA distribution of the ${ }^{3} \mathrm{H}$-thymidine-labelled cells did not differ significantly from that of a normal marrow.

The DNA contents of selected polyploid and multinucleate cells were compared with the DNA contents of 100 randomly chosen, unlabelled, diploid cells (Fig. 10). The mononuclear polyploid cells had 4 times the DNA content of the 2 n cells, and the multinucleate cells had 8 and 12 times.

\section{Discussion}

Chromosome Studies. The bone-marrow of $\stackrel{\overparen{\oplus}}{\stackrel{\oplus}{+}}$ this patient was populated largely by a cell line with $\overrightarrow{\vec{F}}$ a basic cytogenetic abnormality on which furtherchromosomal variation was superimposed. The basic cytogenetic abnormality involved the absence $\overline{\frac{\sigma}{(n)}}$ of $\mathrm{B}$ and $\mathrm{C}$ chromosomes and the presence of a ring $\widehat{\Phi}$ chromosome which could have been formed from any of the missing $B$ and $C$ chromosomes. The ${ }^{\infty}$ variable size of the ring chromosome suggested that $\vec{O}$ it was sometimes unstable at mitosis, and that breakage of the ring was followed by its reconstitution. $\stackrel{\omega}{\circ}$ The varying numbers of $\mathrm{C}$ chromosomes and the additional $\mathrm{E}$ and minute elements present in the different sublines may have had their origin in the

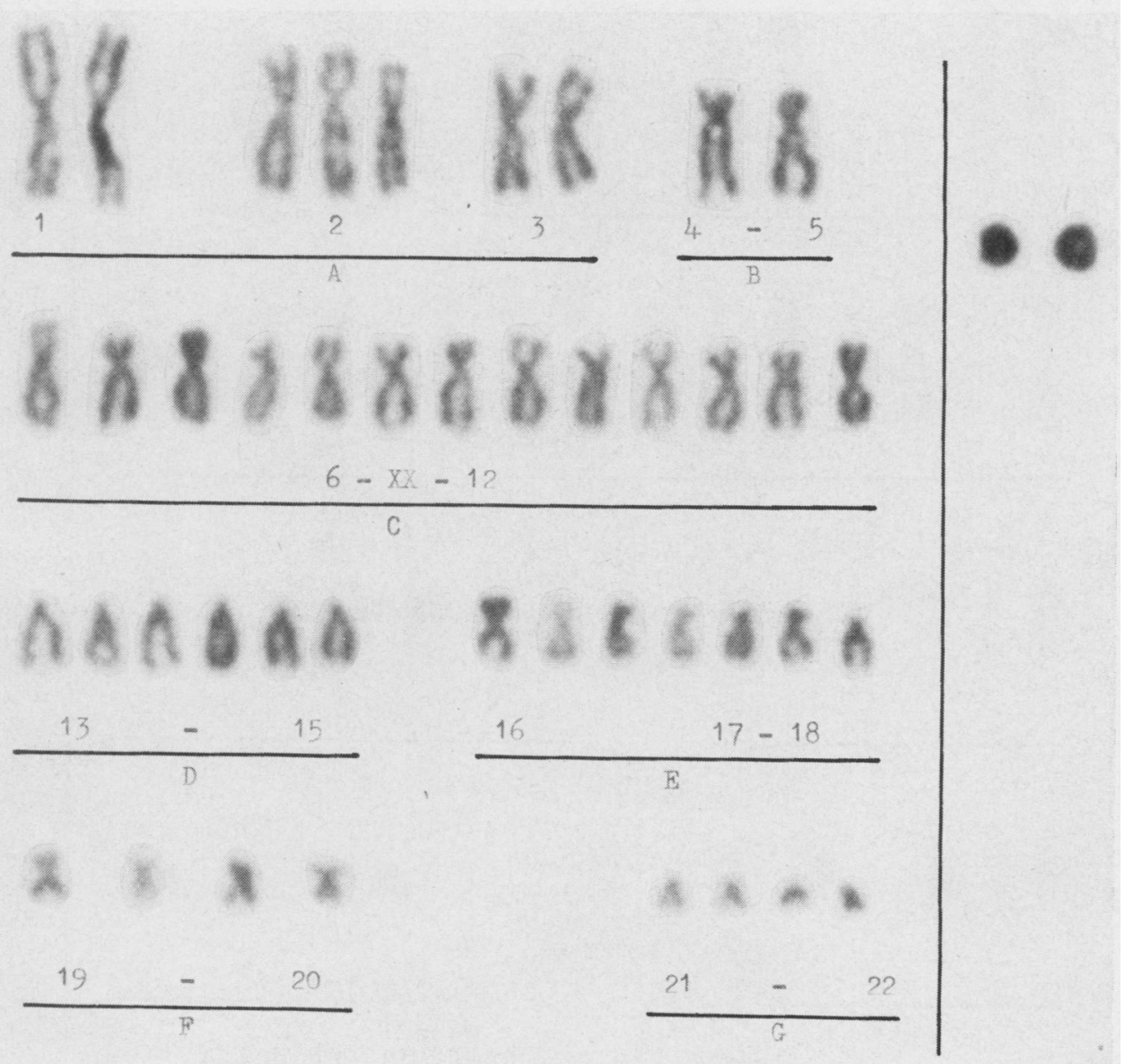

Fig. 5. A bone-marrow cell showing 2 probably identical ring chromosomes. Additional chromosomes are present in the A and $\mathrm{E}$ groups. Two $B$ and three $C$ chromosomes are missing. Total 45 chromosomes. 
mitotic instability of the ring chromosome. Many of the marrow cells also showed chromosome breaks and gaps.

This is the third report of a cell line with a ring chromosome in erythroleukaemia. However, the ring chromosomes do not appear to represent a specific aberration because different chromosomes were involved in each patient: probably a No. $2(\mathrm{Di}$ Grado et al., 1964), C and F chromosomes (Jensen, 1966), and a B or C chromosome in our patient. The presence of a cell line with a ring chromosome in 3 of 31 patients with erythroleukaemia is possibly a measure of the incidence of structurally abnormal cell lines in this disorder. By contrast, among the many reports of other leukaemias we can find only one description of a bone-marrow cell line with a ring chromosome (Sandberg et al., 1962), and this patient with myeloblastic leukaemia had been treated previously with 5-fluorouracil.

Whether therapy measures have played a significant role in the formation of the ring chromosomes in erythroleukaemia is uncertain. The patient of Jensen (1966) with two ring chromosomes developed leukaemia after several series of radiotherapy for spondylitis; no reference is made to previous therapy in the report of Di Grado et al. (1964); and our own patient was untreated. However, cell lines with chromosome structural changes other than rings have been reported in several untreated patients with erythroleukaemia (Fitzgerald,

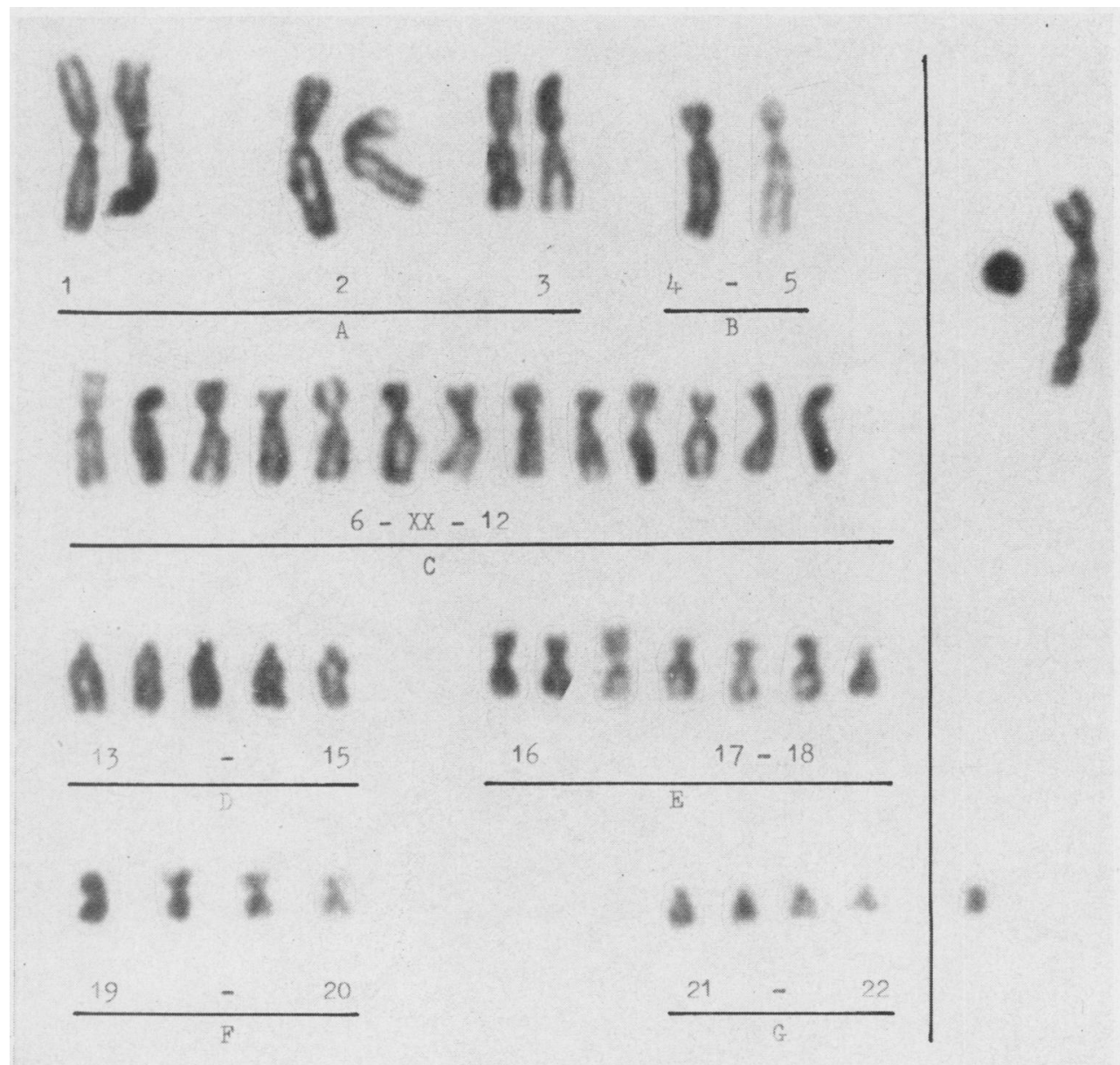

Fig. 6. A bone-marrow cell showing a ring chromosome, a dicentric chromosome, and a minute element. Two B, three C, and one D chromosomes are missing, and there is an additional $\mathrm{E}$ chromosome. Total 44 chromosomes. 
Adams, and Gunz, 1964; Heath and Moloney, 1965; Kiossoglou, Mitus, and Dameshek, 1965).

Structural abnormalities in the polyploid cells were similar to those in the near diploid cells. These polyploid cells probably resulted from the continued action of a factor disturbing cell division, and there was no evidence that they represented a major polyploid clone. Therapy measures which frequently cause polyploidy were absent. Heath (1966) suggested that polyploid cells in erythroleukaemia resulted from disturbance of the mechanism of cell division by a factor inherent in this illness. This factor might be associated with the disturbance of DNA metabolism noted below, though polyploidy is not a feature of megaloblastic anaemia which shows evidence of a similar disturbance.

DNA Studies. Microdensitometric measurements of DNA content in unlabelled cells showed increased spreads of the $2 \mathrm{n}$ and $4 \mathrm{n}$ modes. The chromosomal aneuploidy could have caused much of this. Of greater importance, however, were the unlabelled cells with amounts of DNA between $2 \mathrm{n}$ and 4n. The DNA content of these cells is usual for cells in the $\mathrm{S}$ period of the cell cycle which are actively synthesizing DNA. Consequently, the failure of these cells to label with ${ }^{3} \mathrm{H}$-thymidine suggests either that they had entered the $\mathbf{S}$ period and DNA synthesis had broken down subsequently, or that DNA synthesis in these cells was proceeding at a greatly slowed rate. A similar abnormality of DNA synthesis has been described in megaloblastic anaemia (Menzies et al., 1966).

Impaired DNA synthesis in both the present patient with erythroleukaemia and in megaloblastic anaemia is associated with an increased amount of chromosome aberration, particularly breaks and gaps, in bone-marrow cells. This chromosome damage is of a type which is also caused by many agents known to interfere specifically with DNA metabolism (Menzies et al., 1966; Heath, 1966)

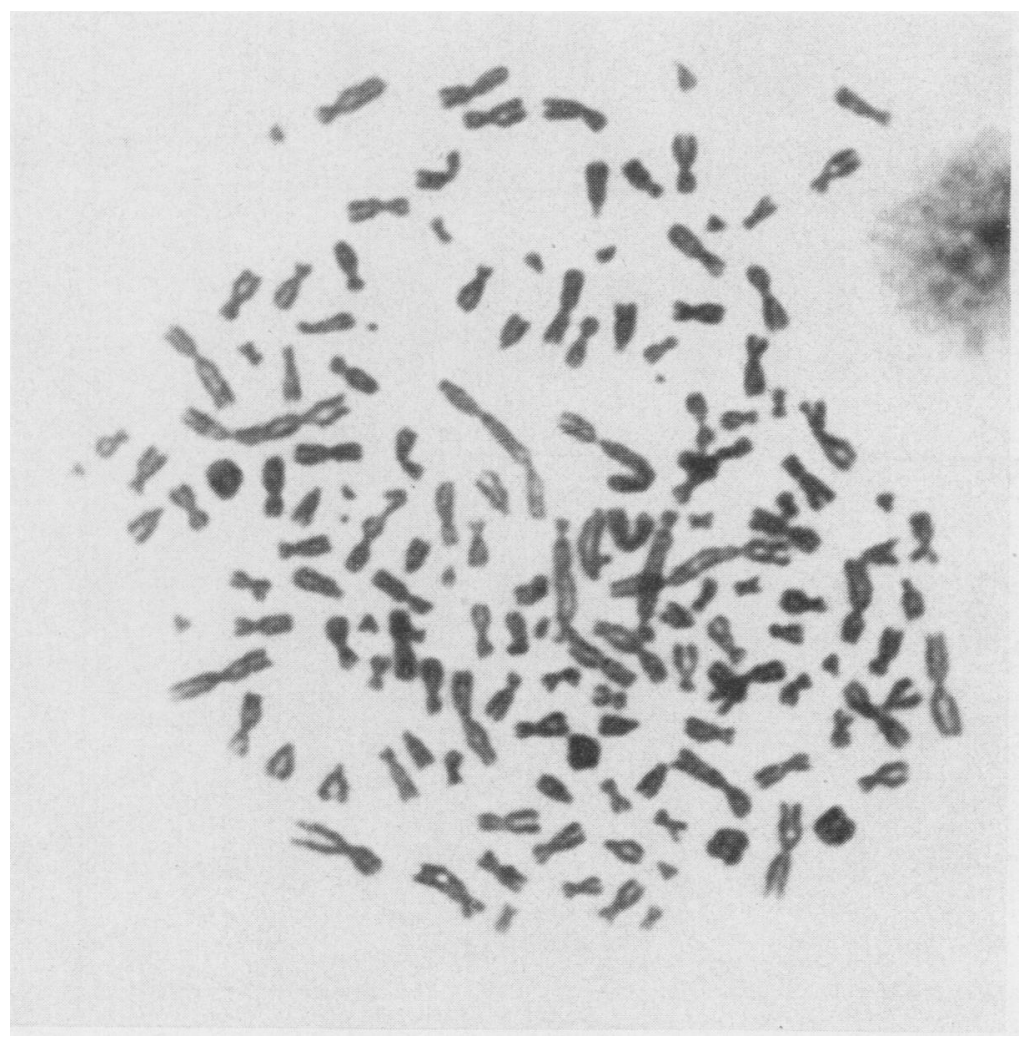

FIG. 7. A bone-marrow cell with approximately 150 chromosomes. There are four ring chromosomes, six dicentrics, and many minute elements. The rings are of similar size. Four of the dicentrics appear to be identical, and differ from the other two in the lengths of the free arms. 


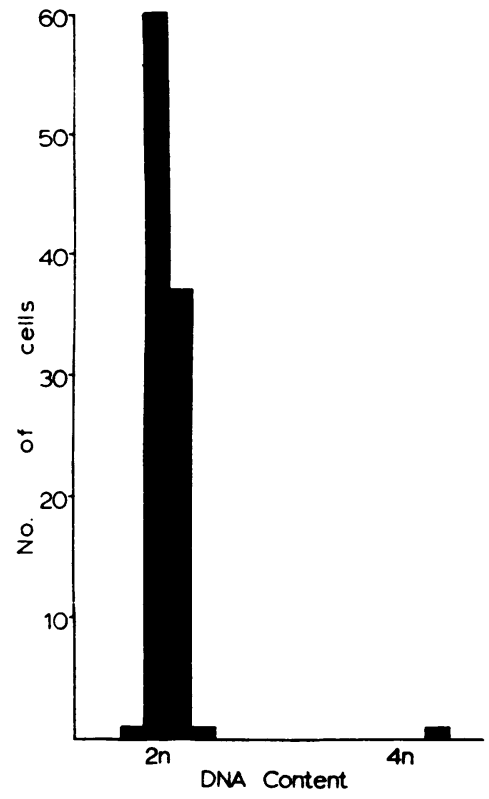

Fig. 8. Histogram of the DNA contents of normal marrow cells. Only cells which did not label with ${ }^{3} \mathrm{H}$-thymidine are shown. The $2 n$ peak represents the post-mitotic cells which have not started DNA synthesis. The $4 \mathrm{n}$ peak represents the pre-mitotic cells which have completed DNA synthesis.

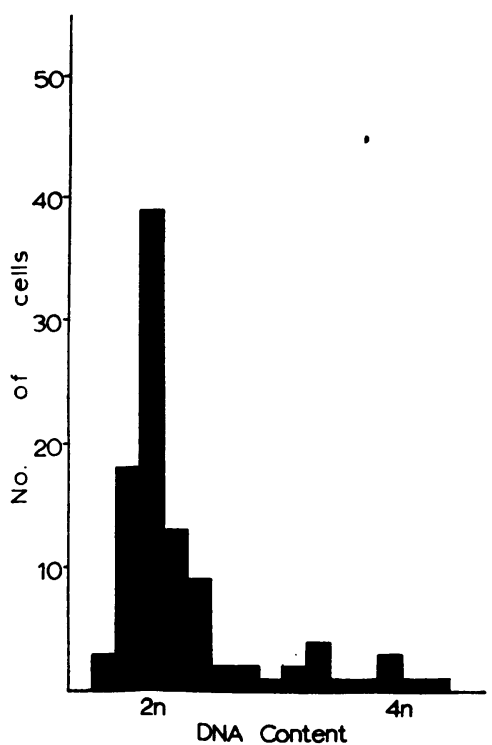

Fig. 9. Histogram of the DNA contents of marrow cells from the patient with erythroleukaemia. Only cells which did not label with ${ }^{3} \mathrm{H}$-thymidine are shown. About $10 \%$ of the cells have amounts of DNA between $2 \mathrm{n}$ and $4 \mathrm{n}$.

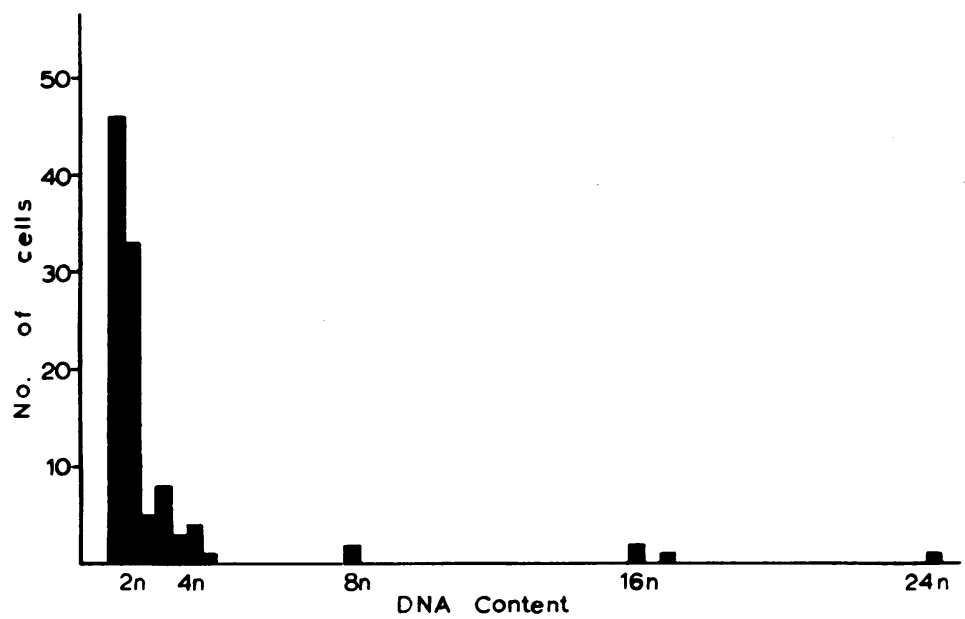

Fig. 10. Histogram of the DNA contents of diploid, polyploid, and multinucleate bone-marrow cells from the patient with erythroleukaemia. The cells with $16 \mathrm{n}$ and $24 \mathrm{n}$ amounts of DNA were multinucleate. All cells, except the multinucleate cell at $24 \mathrm{n}$, did not label with ${ }^{3} \mathbf{H}$-thymidine. 
and a causal relation between the impaired DNA metabolism of these blood disorders and the chromosome damage is probable. Abnormal DNA synthesis might well be the cause of the high proportions of cells and cell lines with chromosome structural changes already noted in erythroleukaemia.

Megaloblastosis, which is often observed in erythroleukaemia, is commonly held to be indicative of abnormal DNA metabolism. This view is supported by the association of the two conditions in marrow cells of the present patient, and also by the almost identical evidence for DNA arrest reported previously in marrow cells of patients with megaloblastic anaemia (Menzies et al., 1966). The exact relation of abnormal DNA synthesis to the developmental abnormality of the erythroid cells is not clear.

The cause of the irregular DNA metabolism in the present patient is unknown. Abnormal DNA metabolism is believed to result from deficiencies of the B12 and folic acid vitamins in megaloblastic anaemia, but the cause must lie elsewhere in erythroleukaemia, because our patient like others with this disorder had normal levels of these vitamins. The impaired DNA metabolism in erythroleukaemia more likely results from a faulty cellular function, possibly an enzyme deficiency, which could be a consequence of the neoplastic change, or possibly a fundamental part of it.

It is suggested that abnormal DNA synthesis is the prime cause of the megaloblastic cell development and of the increased chromosomal structural abnormality which characterizes the present patient and other patients with erythroleukaemia.

\section{Summary}

Bone-marrow cells from a 72-year-old woman with acute erythroleukaemia had abnormal modal counts of 44 and 45 chromosomes, with 2 B group and 2 or more $\mathrm{C}$ group chromosomes absent. $\mathrm{Ab}$ normal elements included a ring chromosome which was present in nearly all cells. The marrow cells also showed increased incidences of chromosome breaks and gaps, and of polyploidy. Com- bined ${ }^{3} \mathrm{H}$-thymidine autoradiography and Feulgen microdensitometry showed abnormal DNA syn- $\stackrel{\overparen{P}}{?}$ thesis in the marrow cells. It is suggested that $\overrightarrow{\vec{F}}$ abnormal DNA synthesis is the prime cause of the megaloblastic cell development and of the increased chromosomal structural abnormality which charac- $\frac{\bar{\omega}}{\sigma}$ terizes the present patient and other patients with $\vec{D}$ erythroleukaemia.

\section{REFERENCES}

Baikie, A. G., Jacobs, P. A., McBride, J. A., and Tough, I. M. (1961). Cytogenetic studies in acute leukaemia. Brit. med. F., 1, 1564.

Balfour, B. M., Cooper, E. H., and Meek, E. S. (1965). DNA metabolism of the immunoglobulin-containing cells in the lymph nodes of rats. 7. reticuloendoth. Soc., 5, 379 .

Buckton, K. E., Jacobs, P. A., Court Brown, W. M., and Doll, R. ? (1962). A study of the chromosome damage persisting after $x$-ray therapy for ankylosing spondylitis. Lancet, 2, 676.

Di Grado, F., Mendes, F. T., and Schroeder, E. (1964). Ring O chromosome in a case of Di Guglielmo syndrome. ibid., 2, 1243.

Durant, J. R., and Tassoni, E. M. (1967). Coexistent DiGuglielmo's leukemia and Hodgkin's disease. A case report with cytogenetic $>$ studies. Amer. F. med. Sci., 254, 824.

Fitzgerald, P. H., Adams, A., and Gunz, F. W. (1964). Chromo- $\widehat{\Omega}$ some studies in adult acute leukemia. F. nat. Cancer Inst., 32, 395.

Harnden, D. G., and Brunton, S. (1965). The skin culture tech- $\overrightarrow{0}$ nique. In Human Chromosome Methodology, p. 57. Ed. by J. J. O Yunis. Academic Press, New York.

Hayhoe, F. G. J., and Hammouda, F. (1965). Cytogenetic and $\square$ metabolic observations in leukaemias and allied states. In Current Research in Leukaemia, p. 55. Ed. by F. G. J. Hayhoe. University Press, Cambridge.

Heath, C. W., Jr. (1966). Cytogenetic observations in vitamin $B_{12}$ O and folate deficiency. Blood, 27, 800.

- and Moloney, W. C. (1965). Cytogenetic observations in a case of erythremic myelosis. Cancer (Philad.), 18, 1495.

Jensen, M. K. (1966). Chromosomal findings in two cases of acute erythro-leukaemia. Acta med. scand., 180, 245.

Kiossoglou, K. A., Mitus, W. J., and Dameshek, W. (1965). Chromosomal aberrations in acute leukaemia. Blood, 26, 610 .

McClure, P. D., Thaler, M. M., and Conen, P. E. (1965). Chronic erythroleukaemia with chromosome mosaicism. Report of a case in a 5-year-old boy. Arch. intern. Med., 115, 697.

Menzies, R. C., Crossen, P. E., Fitzgerald, P. H., and Gunz, F. W. (1966). Cytogenetic and cytochemical studies on marrow cells in $\mathrm{B}_{12}$ and folate deficiency. Blood, 28, 581 .

Moorhead, P. S., Nowell, P. C., Mellman, W. J., Battips, D. M., and 8 Hungerford, D. A. (1960). Chromosome preparations of leukocytes cultured from human peripheral blood. Exp. Cell Res., 20, 613.

Sandberg, A. A., Ishihara, T., Crosswhite, L. H., and Hauschka, T. 금 S. (1962). Chromosomal dichotomy in blood and marrow of acute $D$ leukemia. Cancer Res., 22, 748.

Tjio, J. H., and Whang, J. (1962). Chromosome preparations of bone marrow cells without prior in vitro culture or in vivo colchi- N cine administration. Stain Technol., 37, 17.

Weatherall, D. J., and Walker, S. (1965). Changes in the chromo- N some and haemoglobin patterns in a patient with erythro-leukaemia. N f. med. Genet., 2, 212. 